\section{ПРАВА НА СОЦІАЛЬНИЙ ЗАХИСТ ВНУТРІШНЬО ПЕРЕМІЩЕНИХ ОСІБ}

\section{RIGHTS TO SOCIAL PROTECTION OF INTERNALLY DISPLACED PERSONS}

\author{
ZELINSKA M., \\ Candidate of Political Sciences, \\ Associate Professor, Department of \\ Public Administration and \\ Administration, Donetsk State \\ University of Management \\ NIKITINA O., \\ student
}

У статті розглянуті проблеми вимушено переміщених осіб, що з'явились внаслідок збройного конфлікту на сході Украйни в 2014 роиі. Визначені труднощі, з якими зіткнулась держава після величезного внутрішнього переселення людей з окупованих територій. Проаналізовано заходи для полегшення життя внутрішньо переміщених осіб. Розглянута ефективність державних заходів з вирішення побутових та сочіальних проблем ВПО. Рекомендовані умови комплексної та системної підтримки за участю державних та громадських організачій.

Ключові слова: внутрішньо переміщені особи; сочіальний захист; допомога; ВПО; права людини; громадянське суспільство; сочіальна робота.

В статье рассмотрены проблемы вынужденно перемещенных лии, появившихся в результате вооруженного конфликта на востоке Украинь в 2014 году. Определены трудности, с которыми столкнулось государство после огромного внутреннего переселения людей из оккупированных территорий. Проанализированы действия для облегчения жизни внутренне перемещенных лии. Рассмотрена эффективность государственных мер по решению бытовых и сочиальных проблем ВПЛ. Рекомендованы условия комплексной и системной поддержки с участием государственных и общественных организачий.

Ключевые слова: внутренне перемещенные лица; социальная защита; помощь; ВПЛ; права человека; гражданское общество; сочиильная pабота.

The article deals with the features of internally displaced persons, appeared as a result of armed conflict in eastern Ukraine in 2014. The difficulties are defined, with which the state collided after a huge internal resettlement of people from the occupied territories. Also measures to facilitate the life of internally displaced persons and the effectiveness of government measures to address every day and social problems of IDPs are analyzed. Conditions are recommended for integrated and systemic support with the participation of state and public organizations.

Keywords: internally displaced persons; social protection; assistance; IDP; human rights; civil society; social work. 
Постановка проблеми. Збройний конфлікт у східному регіоні України у 2014 році став причиною появи такого раніше неіснуючого в Україні явища як внутрішньо переміщені особи. Велика кількість переміщених осіб стала болісним соціальним викликом загальнодержавного масштабу, яка породила низку проблем, пов'язаних із забезпеченням житла, працевлаштуванням переселенців, зростанням у зв'язку із цим, навантаження на місцевих ринках праці, пенсійним забезпеченням осіб відповідного віку, влаштуванням дітей і молоді у навчальні заклади різних рівнів, медичним обслуговуванням, психологічною реабілітацією, культурною та соціальною реінтеграцією тощо.

Державою у короткий час було розроблено та впроваджено в дію закони, постанови та інші розпорядження, регулюючи вирішення проблем переселенців, але на жаль, цього виявилося недостатньо. Зокрема, крім матеріальних питань, є багато соціальних та психологічних аспектів. Велику допомогу у цій складній ситуації надають органи місцевого самоврядування, громадські організації, волонтери тощо.

Аналіз останніх досліджень $і$ публікацій. Вітчизняними вченими, такими як: Т. Семигіна, Н. Гусак, С. Трухан, С. Мигашко, Н. Тимошенко, І. Сьомгіна проводився аналіз соціальної підтримки внутрішньо переміщених осіб, їх соціально-психологічних особливостей. Проводився розгляд законодавчої бази, йде робота по її удосконаленню та більшою адаптованістю до знову виникаючих проблем переселенців.

Mema cmammi. Метою статті $\epsilon$ визначення проблем внутрішньо переміщених осіб, аналіз вирішення їх державою та допомога інших громадських організацій.

Виклад основного матеріалу дослідження. Вимушено переміщені особи, як одна 3 категорій населення, яка опинилася в складних життєвих обставинах у зв'язку 3 вимушеною міграцією, з'явилась в Україні перед березневим референдумом в Криму у 2014 році, а також у зв'язку із збройним конфліктом у східному регіоні України та анексією Криму. Внутрішнє переміщення в Україні $з$ того часу почало стабільно зростати. Так, за офіційними даними Управління Верховного комісара ОOH у справах біженців (UNHCR) на 11 вересня 2019 року зафіксовано 1408350 осіб зі статусом внутрішньо переміщених [1].

Найбільші потоки внутрішнього переміщення осіб спрямовані у східні та центральні регіони України (Луганська, Харківська, Донецька, Дніпропетровська, Запорізька області та м. Київ). В Донецькій області на обліку в структурних підрозділах з питань соціального захисту населення фактично перебуває станом на 11.09.2019 р. 495796 осіб, в Луганській області - 274619 осіб, в місті Київ 152 752, в Харківській області - 131434 [1].

Проте за даними ООН близько 2,3 млн осіб вимушено залишили свої домівки у зоні конфлікту і виїхали в інші регіони України та за кордон [2, с.233].

Ключові проблеми, що постають перед внутрішньо переміщеними особами (ВПО), на думку представників Управління Верховного комісара ООН у справах біженців в Україні, - це доступ до соціальних послуг, наявність постійного житла та оформлення реєстрації за новим місцем проживання. Чинниками, що певною мірою пом'якшують процеси адаптації внутрішніх переселенців в Україні, є те, що ці особи навіть після переселення залишаються громадянами України, отже, 
не потребують послуг імміграційних служб, оформлення документів та вид проживання тощо; потрапляючи в нові умови життя, вони лишаються, тим не менше, в слов'янському (до якого відноситься більшість внутрішніх переселенців) ментальному, мовному, етнокультурному просторі, практично не стикаються з проблемою необхідності вивчення принципово незнайомої їм мови, що також полегшує їх реінтеграцію на новому місці проживання. Проте ці фактори повністю не знімають проблем ВПО в Україні, отже, потребують, в першу чергу, особливої уваги з боку української держави.

Одним із важливих напрямків соціальної політики держави стосовно ВПО є розробка відповідної законодавчої бази.

У реалізації відповідних державних документів задіяні Міністерство соціальної політики України, Міністерство регіонального розвитку, будівництва та житлово-комунального господарства України, Міністерство інфраструктури України, Міністерство фінансів України, Міністерство охорони здоров'я України, Міністерство інформаційної політики України, Міністерство культури України, Міністерство молоді та спорту України, Донецька та Луганська військовоцивільні адміністрації, департаменти відповідних міністерств і відомств, інші державні структури, органи місцевого самоврядування.

На сьогоднішній день в Україні існує близько двох десятків законів, постанов, розпоряджень відповідних органів, що регулюють вирішення проблем ВПО [3]. Водночас існує потреба в узгодженні механізмів реалізації цих законів, посиленні державного контролю щодо їх виконання, узгодження терміну дії довідок внутрішньо переміщених осіб в різних державних актах, погодженні дій міністерств при виконанні державних законодавчих рішень. Важливу роль у вирішенні проблем внутрішньо переміщених осіб відіграють різноманітні державні соціальні служби, в першу чергу - Міністерство соціальної політики України.

Безперечно, вимушено переміщені особи потребують різного роду допомоги. Найчастіше, на облік стають ті люди, яким необхідна допомога в отриманні пенсій, соціальних виплат, пошуку роботи, житла, засобів для існування тощо.

В основному, правове забезпечення повинно бути спрямоване на вирішення таких основних проблем ВПО: працевлаштування дорослих членів сім’ї; пошук місця проживання, житла, тимчасове розміщення вимушених переселенців; регуляція процедури оформлення необхідних документів для отримання матеріальної допомоги; відкриття банківського рахунку для тримання соціальних допомог; оформлення паспорта громадянина України; отримання акту фактичного проживання; інформування щодо необхідності реєстрації в державному реєстрі виборців для можливості голосувати за місцем перебування; надання гуманітарної допомоги (одяг, взуття, іграшки для дітей); отримання продуктового набору; консультування щодо отримання посвідчення багатодітної сім’ї; надання психологічної підтримки; влаштування дітей шкільного віку в загальноосвітні навчальні заклади міста, при можливості та наявності місць - у дошкільні навчальні заклади, студентів - у ВНЗ та ПТУ тощо; консультування щодо тимчасової реєстрації дитини в міграційній службі; організація дозвілля, залучення до благодійних заходів; регуляція роботи благодійних фондів та громадських організацій, які надають допомогу вимушеним переселенцям. 
Українське законодавство намагається вирішити ряд проблем, які постають перед ВПО. Наприклад, згідно з постановою Кабінету міністрів України «Про надання щомісячної адресної допомоги особам, які переміщуються 3 тимчасово окупованої території України та районів проведення антитерористичної операції, для покриття витрат на проживання, у тому числі на оплату житлово-комунальних послуг» № 505 від 01.10.2014 р. (поточна редакція від 05.09.2018) [4] державна допомога здійснюється шляхом надання щомісячної адресної допомоги. На допомогу можуть розраховувати громадяни, які постійно проживають на території України і переміщуються з тимчасово окупованої території України та районів проведення військових дій, а також стоять на обліку в управлінні соціального захисту населення. Максимальний строк виплат - не більше ніж шість місяців. Грошова допомога виплачується одному з членів сім'ї за умови надання письмової згоди довільної форми про виплату грошової допомоги цій особі від інших членів сім'ї у таких розмірах:

для непрацездатних осіб - 1000 грн на одну особу (члена сім’ï);

для осіб з інвалідністю I групи та дітей з інвалідністю - 130 відсотків прожиткового мінімуму для осіб, які втратили працездатність ( з 01.07.2019 року 2033,20 грн);

для осіб з інвалідністю II групи - 115 відсотків прожиткового мінімуму для осіб, які втратили працездатність (з 01.07.2019 року 1798,60 грн);

для осіб з інвалідністю III групи - прожитковий мінімум для осіб, які втратили працездатність (з 01.07.2019 року 1564,00 грн);

для працездатних осіб - 442 грн на одну особу (члена сім’ï).

Загальна сума допомоги на сім'ю розраховується як сума розмірів допомоги на кожного члена сім’ї та не може перевищувати 3000 грн.; для сім’ї, до складу якої входять особи 3 інвалідністю або діти 3 інвалідністю, - 3400 грн; для багатодітної сім’ї- 5000 гривень.

Надання адресної допомоги у зазначеному розмірі безумовно полегшує життя ВПО, проте не вирішує більшості проблем. У тому числі - й проблеми 3 житлом, оскільки оренда житла в містах, де можна знайти роботу, коштує набагато дорожче.

Неврегульованим є питання існування чіткої стратегії повернення частини переселенців назад на окуповані території. Отже, повинно бути зрештою розв'язане питання із єдиною реєстрацією ВПО, укладеною за прозорими принципами з обліком всіх різновидів допомоги, включно із допомогою, наданою міжнародними проектами, фондами, програмами. Необхідно розробити чіткий механізм та критерії відбору для надання допомоги внутрішньо переміщеним особам залежно від їхнього матеріального стану та соціального статусу. Нормативно-правову базу у даній сфері необхідно вдосконалювати, адже вона $є$ механізмом реалізації активних дій підтримки та захисту вимушено переселених осіб. Бездіяльність держави може призвести до погіршення ситуації у суспільстві, виникнення напруги у стосунках між ВПО та місцевим населенням зони переселення, а також до використання зростаючого невдоволення для подальшої дестабілізації ситуації в країні.

Житлове питання є однією з найбільш гострих проблем, які постають перед внутрішньо переміщеними особами в Україні. 
Відповідно до Закону України «Про забезпечення прав і свобод внутрішньо переміщених осіб» [5], держава має забезпечити умови для вільного переміщення ВПО всередині країни, надання їм житла чи притулку, особам яких змусили залишити або покинути своє місце проживання у результаті або 3 метою уникнення негативних наслідків збройного конфлікту, тимчасової окупації, повсюдних проявів насильства, порушень прав людини та надзвичайних ситуацій природного чи техногенного характеру, а також створення умов для добровільного повернення та реінтеграції ВПО на місцях попереднього проживання. Згідно з абз. 7 ч. 1 ст. 9 Закону України «Про забезпечення прав $\mathrm{i}$ свобод внутрішньо переміщених осіб» [5], ВПО мають право на безоплатне тимчасове проживання (за умови оплати особою вартості комунальних послуг) протягом шести місяців з моменту взяття їх на облік, для багатодітних сімей, інвалідів, осіб похилого віку цей термін може бути продовжено.

Основний тягар вирішення проблем з поселенням переселенців у державі був покладений на місцеві органи виконавчої влади та громадську владу. На державному рівні досі не визначено ані порядку надання житла для ВПО, та відповідальних осіб за цей процес. Крім того, не затверджено програму та порядок надання пільгових/іпотечних довготермінових кредитів на придбання земельних ділянок, будівництва чи купівлю житла для ВПО. Тож, фактично, держава обрала шлях з поселення ВПО на тимчасових умовах на об'єктах, що перебувають у державній/комунальній власності (гуртожитках, санаторіях, таборах, готелях). До порядку розміщення ВПО залучається багато департаментів облдержадміністрацій, включно із соціальними службами, центрами зайнятості, контактними центрами.

Ефективність державних заходів 3 вирішення житлових проблем ВПО демонструють дані, наведені головою Всеукраїнської організації зі справ вимушених переселенців: так, 95\% вимушених переселенців винаймають помешкання за власні кошти, і лише близько 5\% живуть у місцях компактного проживання. При цьому майже $40 \%$ людей, які залишили зону бойових дій, ніколи вже не збираються повертатися, і ще стільки ж, за її словами, залишилися б на новому місці - за умови вирішення житлового питання [6].

Більш детальні дані про типи помешкань, де проживають ВПО, надають дослідження організації The Global Shelter Cluster (GSC), згідно з опитуванням якої виявилося, що більшість ВПО проживала в орендованих помешканнях, а приблизно третина - на правах гостей. Близько $5 \%$ повідомили, що вони $\epsilon$ власниками теперішнього житла, ще меншою виявилася кількість родин, які проживають у готелях чи інших типах житла [7].

Складність ситуації з поселенням ВПО також полягає в тому, що внутрішнє переміщення таких вимушених мігрантів по території держави змушує публічну адміністрацію передбачати як короткострокові, так і довгострокові плани 3 вирішення їх проблем. Прикладом чого може слугувати необхідність знаходження для осіб із числа ВПО не лише тимчасового житла, а й створення умов для їх «стійкого розселення» - знаходження для них постійного житла (шляхом створення нових житлових об'єктів, гнучких систем кредитування, приватизації помешкань, які ВПО займають тимчасово, тощо.

Сьогодні держава здатна посприяти в отриманні переселенцями житла на постійній основі лише опосередковано: через державні житлові програми, 
виділення земельних ділянок під будівництво та видачу ордера на жиле приміщення для осіб з позачергової/ пільгової/звичайної квартирної черги. Окремі житлові програми для ВПО відсутні.

В житловому законодавстві України наявні суттєві колізії та прогалини. Його норми досі не приведено у відповідність до норм Закону «Про забезпечення прав і свобод внутрішньо переміщених осіб» [5] та навпаки. На державному рівні вже розроблено три способи врегулювання житлових потреб ВПО: надання тимчасового житла (з соціального та тимчасового комунального житлового фондів, за сприяння міжнародних донорів -поселення в модульні містечка); організація виплати адресної грошової допомоги для покриття витрат на проживання, в тому числі на оплату житлово-комунальних послуг; часткове створення умови для отримання постійного житла (зокрема, через програму “Власний дім” для індивідуального житлового будівництва на селі). Втім аналіз законодавчих актів показав, що на законодавчому рівні відсутнє врегулювання першочергового права ВПО на отримання житла із соціального фонду, не враховано нестачу тимчасового житлового фонду, відсутні преференції для ВПО при постановленні на квартирну чергу. Першочерговими заходами з боку держави для вирішення житлових проблем ВПО повинні стати розробка та імплементація стимулів до розосередження переселенців по різних регіонах країни, яке повинно збігатися з політикою регіонального розвитку держави. Необхідно розглядати ВПО як значний соціальний ресурс для відродження інфраструктури малозаселених міст та сільських місцевостей при правильному бюджетуванні таких населених пунктів та управлінні міграцією.

Дуже важливою $є$ соціальна робота 3 переселенцями, які зазнали чимало труднощів та в більшості пережили стреси, потрясіння та навіть втрати близьких. При роботі 3 переміщеними особами соціальні працівники України, використовуючи світовий та європейський досвід соціальної роботи, застосовують різноманітні стратегії роботи, які носять комплексний характер: короткострокові (кризове втручання, аутріч-робота, орієнтована на завдання модель соціальної роботи) та довгострокові (пов'язані з системно-екологічною моделлю соціальної роботи, в основі яких знаходяться концепція «людина в оточенні» та концепція «економічної спроможності») [8].

Важливим напрямком роботи соціальних працівників та соціальних педагогів $\epsilon$ надання соціально-психологічної підтримки ВПО. Проблеми психологічного стану біженців-переселенців, що опиняються в стані екстремальної, або, щонайменше, кризової для них ситуації, $є$ одними із провідних у процесі їх адаптації у нове соціальне середовище. Процес пристосування до нових умов життя представників зазначених категорій населення проходить ряд етапів [9]: «ейфорійна» фаза (триває від декількох днів до декількох місяців), коли не відбувається особливих змін у ії поведінці з точки зору різноманітних перспектив діяльності, захоплень, уподобань, інтересів тощо; «туристична» фаза - на цьому етапі переміщена особа починає поступово отримувати інформацію про нове для неї суспільне середовище; «орієнтаційна фаза» - період, коли внутрішньо переміщена особа вирішує різноманітні особистісні проблеми, пов'язані з поступовим пристосуванням до умов нового етнічного, економічного, соціального, культурного середовища; «депресивна» фаза, через яку проходять всі переселенці, які, за умови успішності чи 
неуспішності її подолання або стають активними членами нового соціуму («фаза активної діяльності»), або, навпаки, дезадаптують, що супроводжується соціальною апатією, психічними розладами, стресами, алкоголізмом тощо.

Отже, при визначенні стратегії надання психологічної допомоги ВПО соціальні працівники повинні враховувати не лише зазначені етапи адаптації, а й результати попередньої диференціації переселенців на основі критерію перенесених людиною втрат [10]. Загалом, надання допомоги сім'ям переселенців повинно мати комплексний характер і не зводитись лише до матеріальної, фінансової чи медичної, як показує практика. Одним із основних якісних індикаторів рівня соціального розвитку держави $\epsilon$ висока ступінь участі громадянського суспільства у вирішенні соціальних проблем. Поширеним підходом у визначенні громадянського суспільства $\epsilon$ розуміння, що це $\epsilon$ «третій сектор» - сфера соціальної активності, в першу чергу, неурядових, неприбуткових організацій. Інституціями громадянського суспільства виступають громадські, благодійні, волонтерські організації, різноманітні спілки, спортивні клуби, окремі освітні та медичні організації, аналітичні центри тощо. Саме ці суб'єкти соціальної політики в силу своєї наближеності до людини та відсутності бюрократичних ланцюгів здатні оперативно реагувати на соціальні запити та вирішувати відповідні проблеми.

Прикладом взаємодії державних органів і громадянського суспільства у вирішення проблем ВПО $є$ Програма «Посилення участі громадського суспільства у роботі Міністерства соціальної політики України та процесі національного примирення», розпочата у вересні 2015 року Мінсоцполітики України спільно 3 громадською організацією «КримSOS» та Міжнародною організацією «Stabilization Support Services» за підтримки уряду Великобританії, метою якої $є$ соціальний захист внутрішньо переміщених осіб та інших незахищених громадян України в різних населених пунктах нашої держави [11]. Реалізація ГО України різноманітних проектів із зазначеної проблеми відбувається практично у всіх областях України.

Висновки та перспективи подальших досліджень. Ймовірно, однією з умов успішного вирішення державою у співпраці 3 громадянським суспільством проблем ВПО є створення при Міністерстві соціальної політики України Сдиного Інформаційного Центру, який би став основним осередком акумуляції всієї (наукової, юридичної, статистичної, економічної, грантової, культурної, медичної та ін.) інформації для координації дій всіх суб'єктів, причетних до подолання вказаної проблеми. Як перспективу досліджень можна говорити про подальшу розробку ролі громадянського суспільства у даній проблематиці, а також необхідність вироблення науково обгрунтованих рекомендацій для соціальних працівників, груп активістів щодо забезпечення комплексної та системної підтримки, соціальної адаптації та інтеграції переселених громадян.

\section{Лimepamypa:}

1. Управління Верховного комісара ОOH у справах біженців (UNHCR): офіційний сайт Registration of Internal Displasement. URL: https://app.powerbi.com/view?r=eyJrIjoiY2RhMmExMjgtZWRIMS00YjcwLWI0Mzk tNmEwNDkwYzdmYTM0IiwidCI6ImU1YzM3OTgxLTY2NjQtNDEzNC04YTBjLT Y1NDNkMmFmODBiZSIsImMiOjh9. 
2. Сировий О.В., Чураєва А.С. Засоби міжнародно-правового врегулювання збройного конфлікту на Сході України. Юридичний науковий електронний журнал. 2015. № 6. С. 232-235.

3. Внутрішньо переміщені особи. URL: http://unhcr.org.ua/en/2011-08-2606-58-56/news-archive/2-uncategorised/1293- vnutrishno-peremishcheni-osobi.

4. Про надання щомісячної адресної допомоги особам, які переміщуються з тимчасово окупованої території України та районів проведення антитерористичної операції, для покриття витрат на проживання, у тому числі на оплату житлово-комунальних послуг: Закон України від 01.10.2014p. URL: http://zakon2.rada.gov.ua/ laws/show/505-2014-\%D0\%BF.

5. Про забезпечення прав і свобод внутрішньо переміщених осіб: Закон України від 20.10.2014 № 1706-VII. URL: http://zakon0.rada.gov.ua/laws /show/1706-18.

6. Стадник Г. Житло для переселенців: допоможи собі сам. Львівська пошта. 2016. № 33 (1792). URL: http://www.lvivpost.n.

7. Аналіз потреб 3 питань житла та непродовольчих товарів: Звіт Інформаційний бюлетень кластеру 3 питань житла. 2015. 39 с. URL: http://www.sheltercluster.org/sites/default/files/.

8. Семигіна Т., Гусак Н., Трухан С. Соціальна підтримка внутрішньо переміщених осіб. URL: http://www.ekmair.ukma.edu.ua/handle/123456789/7491.9.

9. Мигашко Є., Тимошенко Н. Соціально-психологічні особливості біженців. URL: http://elibrary.kubg.edu.ua/ 5928.

10. Сьомкіна I. Соціально-педагогічна робота 3 сім'ями вимушених переселенців: стан та перспективи. Збірник наукових праць Хмельницького інституту соціальних технологій Університету «Україна». 2015. № 11. С. 76-83.

11. Мінсоцполітики започатковано Програму «Посилення участі громадського суспільства у роботі Міністерства соціальної політики України та процесі національного примирення». URL: http://www.mlsp.gov.ua/labour/control/ uk/publish/article?art_id=182938\&cat_id=169 302.

References:

1. Upravlinnja Verkhovnogho komisara OON u spravakh bizhenciv (UNHCR): oficijnyj sajt Registration of Internal Displasement. URL: https://app.powerbi.com/view?r=eyJrIjoiY2RhMmExMjgtZWRIMS00YjcwLWI0Mzk tNmEwNDkwYzdmYTM0IiwidCI6ImU1YzM3OTgxLTY2NjQtNDEzNC04YTBjLT Y1NDNkMmFmODBiZSIsImMiOjh9.

2. Syrovyj O.V., Churajeva A.S. Zasoby mizhnarodno-pravovogho vreghuljuvannja zbrojnogho konfliktu na Skhodi Ukrajiny. Jurydychnyj naukovyj elektronnyj zhurnal. 2015. \# 6. S. 232-235.

3. Vnutrishnjo peremishheni osoby. URL: http://unhcr.org.ua/en/2011-08-2606-58-56/news-archive/2-uncategorised/1293- vnutrishno-peremishcheni-osobi.

4. Pro nadannja shhomisjachnoji adresnoji dopomoghy osobam, jaki peremishhujutjsja $\mathrm{z}$ tymchasovo okupovanoji terytoriji Ukrajiny ta rajoniv provedennja antyterorystychnoji operaciji, dlja pokryttja vytrat na prozhyvannja, u tomu chysli na oplatu zhytlovo-komunaljnykh poslugh: Zakon Ukrajiny vid 01.10.2014r. URL: http://zakon2.rada.gov.ua/ laws/show/505-2014-\%D0\%BF. 
5. Pro zabezpechennja prav i svobod vnutrishnjo peremishhenykh osib: Zakon Ukrajiny vid 20.10.2014 № 1706-VII. URL: http://zakon0.rada.gov.ua/laws /show/1706-18.

6. Stadnyk Gh. Zhytlo dlja pereselenciv: dopomozhy sobi sam. Ljvivsjka poshta. 2016. \# 33 (1792). URL: http://www.lvivpost.n.

7. Analiz potreb $\mathrm{z}$ pytanj zhytla ta neprodovoljchykh tovariv: Zvit Informacijnyj bjuletenj klasteru $\mathrm{Z}$ pytanj zhytla. 2015. $39 \mathrm{~s}$. URL: http://www.sheltercluster.org/sites/default/files/.

8. Semyghina T., Ghusak N., Trukhan S. Socialjna pidtrymka vnutrishnjo peremishhenykh osib. URL: http://www.ekmair.ukma.edu.ua/handle/123456789/ 7491.9.

9. Myghashko Je., Tymoshenko N. Socialjno-psykhologhichni osoblyvosti bizhenciv. URL: http://elibrary.kubg.edu.ua/ 5928.

10. Sjomkina I. Socialjno-pedaghoghichna robota $\mathrm{z}$ sim'jamy vymushenykh pereselenciv: stan ta perspektyvy. Zbirnyk naukovykh pracj Khmeljnycjkogho instytutu socialjnykh tekhnologhij Universytetu «Ukrajina». 2015. \# 11. S. 76-83.

11. Minsocpolityky zapochatkovano Proghramu «Posylennja uchasti ghromadsjkogho suspiljstva $\mathrm{u}$ roboti Ministerstva socialjnoji polityky Ukrajiny ta procesi nacionaljnogho prymyrennja». URL: http://www.mlsp.gov.ua/labour/ control/uk/publish/article?art_id=182938\&cat_id=169302.

Armed conflict in the eastern region of Ukraine in 2014 was the cause of appearing such previously nonexistent phenomena in Ukraine as internally displaced persons. A large number of displaced persons became a painful social challenge of the national scale, bare a number of problems related with providing of provision, employment of IDPs, growth in connection with the burden on local markets. Providing children, youth in educational establishments of different levels, medical care, psychological rehabilitation, cultural and social reintegration, and so on.

The state in a short time was developed and implemented laws, regulations and other orders regulating the problems of IDPs, but, unfortunately, it was not enough. Internally displaced persons receive a monetary addressing help which certainly facilitates life, but does not solve most problems. Including problems with housing, because the rent of housing in Cities where you can find a job is much more expensive. In particular, in addition to material issues, there are many social and psychological aspects. The main burden of solving problems with the settlement of IDPs in the state was laid to local executive authorities and public authorities. Great help in this difficult situation is provided by local self-government bodies, public organizations, volunteers, etc.

Insinging, the problem of IDPs is to cooperate with the state Civil society. In General, assistance to families of IDPs must have complex character and not constructed only to material, financial or medical, as practice shows. An important focus of social workers and social pedagogues is to provide Psychosocial support to internally displaced persons. The problems of the psychological state of refugees who find themselves in extreme or, at least, crisis situations for them are among the leading ones in the process of adapting them to the new social environment. 